\title{
Article \\ Influence of Abiotic and Biotic Factors on Soil Microbial Biomass in Robinia pseudoacacia Plantations in the Loess Hilly Region
}

\author{
Wenyan Xue, Yunming Chen*D, Congguo Dong and Yuning Qiao \\ Institute of Soil and Water Conservation, Northwest A\&F University, Yangling 712100, China; \\ 050822@nawfu.edu.cn (W.X.); dong3961@163.com (C.D.); zhiqian11466@163.com (Y.Q.) \\ * Correspondence: ymchen@ms.iswc.ac.cn; Tel.: +86-13-619-250-234
}

check for updates

Citation: Xue, W.; Chen, Y.; Dong, C.; Qiao, Y. Influence of Abiotic and Biotic Factors on Soil Microbial Biomass in Robinia pseudoacacia Plantations in the Loess Hilly Region. Forests 2021, 12, 501. https:// doi.org/10.3390/f12040501

Academic Editor: Keizo Hirai

Received: 1 March 2021

Accepted: 14 April 2021

Published: 16 April 2021

Publisher's Note: MDPI stays neutral with regard to jurisdictional claims in published maps and institutional affiliations.

Copyright: (c) 2021 by the authors. Licensee MDPI, Basel, Switzerland. This article is an open access article distributed under the terms and conditions of the Creative Commons Attribution (CC BY) license (https:/ / creativecommons.org/licenses/by/ $4.0 /)$.

\begin{abstract}
The ecological productivity of the Robinia pseudoacacia L. (RP) widely cultivated on the Loess hilly region has been widely questioned with its aging. Soil microbial biomass (SMB) plays a key role in soil nutrient dynamics and productivity of the ecosystems. Understanding the main ecological drivers of SMB is supposed to be of importance for ecosystem functioning of RP in the Loess hilly region. In this study, we identified the most influential factors affecting SMB at 2 layers $(0-10 \mathrm{~cm}$ and 10-30 cm) using forward selection in terms of plant characteristics (forest age, tree height, diameter at breast height, tree canopy, crown base height, herb height, herb number, herb coverage, herb ground diameter and herb diversity), soil physiochemical characteristics (soil bulk density, pH, water content, soil organ carbon, soil total and available nutrient content) and topographical properties (elevation, aspect and slope). We also analyzed individual and interactive effects (plant-soil, plant-topography, soil-topography, plant-soil-topography) using general linear model (GLM) analysis. Among all plant variables, tree canopy and understory richness had the greatest impact on SMB. The soil variables with the greatest impact on SMB were bulk density and available phosphorus. Elevation was the most important topographic factor affecting SMB. When we considered the interactive effects among plant, soil physicochemical and topographical variables on SMB, a significant interaction effect occurred at a depth of 10-30 cm soil layer. We concluded that individual effects of abiotic and biotic factors significantly affect SMB at $0-10 \mathrm{~cm}$, while the interaction of these factors mainly played roles at 10-30 $\mathrm{cm}$. These results provide a basis for maintaining soil health and productivity using efficient SMB by providing suitable abiotic and biotic habitats.
\end{abstract}

Keywords: Robinia pseudoacacia; driving factors; interactive effect; forward selection; general linear model

\section{Introduction}

Belowground soil microbes are important for forest ecosystem sustainability and functioning [1,2]. They take parts in carbon and nutrient turnover, nutrient mobilization/immobilization, humification, and maintenance of the soil structure [3-5]. Among the various microbial characteristics, soil microbial biomass (SMB) is regarded as the most satisfactory index to estimate ecosystem productivity [6,7], which is the major reservoir of available nutrients [8] and the balance between the release and sequestration of soil carbon [9]. Identifying the main drivers of SMB is important to better understand the function of soil microorganisms in regulating ecosystem structure, process and functioning.

Previous researches have reported the effect of plant, soil and topography on SMB [10]. Plant properties have significant effect on SMB by providing carbon source including leaf litter and root inputs to soil microbes and by altering living environment of microorganisms through root exudates [11]. Abiotic factors (soil and topography) are considered as more important influential factors for changes of the soil microbes compared to plant variables in local scales [12]. SMB may be affected by soil nutrient content [13], soil water content [14], 
soil physical structures [15], slope aspect [16], slope position and elevation [17]. However, to our knowledge, few studies have identified the drivers of SMB at different soil depths, which impedes the understanding of how SMB adapts to soil resources and conditions in soil profiles.

The effect of plant, soil and topographical factors on SMB is closely interrelated and subsequently affects SMB. Plants can directly affect microbial biomass, and they can interact with soil and/or topographical factors. Similarly, soil and topographic factors can also affect SMB directly or together with other factors. Previous studies have reported the interactive effects of vegetation, soil texture, and topography on soil nutrients. For example, a study on shortgrass steppe showed that the lower the slope, the more grasses above the ground, which leads to a much higher soil nutrient concentration. [18]. As mentioned above, although numerical studies have examined the effects of vegetation, soil and topography on SMB and tried to explain the mechanisms behind the effects, however, little is known about the effects of plant-soil-topography interactions on SMB along soil profiles.

The Loess hilly region of China has experienced sever soil erosion and desertification for centuries [19]. Since the 1950s, several afforestation projects have been carried out for soil erosion control and ecosystem restoration [20]. To date, 9.27 million ha of sloping croplands have been revegetated to grasslands or forestlands [21] and $>90 \%$ of the revegetation areas covers Robinia pseudoacacia L. (RP) [22] due to its tolerance to a wide range of natural conditions and strong ability to improve soil nutrient conditions via N-fixing rhizobium [23]. However, RP reforestation in this region have suffered from severe ecosystem degradation nowadays [22]. For example, biomass accumulation and small growth rate (tree diameters, height and crown diameter) and understory diversity were low, the soil nutrient, microbial composition and soil enzyme activity in RP forest all declined to varying degrees [24]. Wei et al. [25] has systematically analyzed the mechanisms of RP plantations degradation from the perspectives of ecology (climatic change, community structure and forest management) and physiology (hydraulic features, genetic and molecular regulation). To our knowledge, however, few studies has examined the causes of low productivity of $\mathrm{RP}$ plantations in terms of abiotic, biotic and their interactions, leading to our knowledge gap of the decline mechanism of RP plantations.

Here in this study, we collected abiotic (soil and topography) and biotic factors (plant) affecting SMB from RP plantations in the Loess hilly region in northern Shaanxi. We hypothesize that (1) SMB at $0-10 \mathrm{~cm}$ is affected more by plants as there are more plant inputs in the topsoil layer, and (2) the plant, soil, and topographical factors would affect $\mathrm{SMB}$, but the interaction would depend on the soil layers. The main objectives were to (1) identify the main plant, soil and topography factors affecting SMB at different depths; (2) analyze the interaction of soil, plant and topographical properties on SMB at different depths. Given the importance of SMB dynamics in ecosystem functioning, we expect to provide more insight into the mechanisms of plant-microbe-soil-topography associations combating soil degradation in the Loess hilly region.

\section{Materials and Methods}

\subsection{Description of Study Area}

The study was conducted in the Zhifanggou watershed $\left(36^{\circ} 30^{\prime}-37^{\circ} 39^{\prime} \mathrm{N}, 108^{\circ} 5^{\prime}-109^{\circ} 26^{\prime} \mathrm{E}\right.$, elevation ranges from 1010 to $1400 \mathrm{~m}$ ), located in the Yan river basin in North Shaanxi, China. The study area belongs to temperate semiarid continental climate zone, with mean annual precipitation of $482.7 \mathrm{~mm}$ from 1980 to 2018. Approximately $60 \%$ of the annual rainfall occurs during summer months (from July to September). The mean annual temperature is $8.8^{\circ} \mathrm{C}$. The monthly mean maximum temperature is $35.2^{\circ} \mathrm{C}$ in July, and the monthly mean minimum temperature is $-15.3^{\circ} \mathrm{C}$ in January (China Meteorological Data Service Center). Soil in this region is classified as Loessial soil (IUSS Working group WRB, 2014) with 64\% sand (50-2000 $\mu \mathrm{m}$ in diameter), $24 \%$ silt ( $2-50 \mu \mathrm{m}$ in diameter), and $12 \%$ clay $(<2 \mu \mathrm{m}$ in diameter). The land use type in the study area currently include croplands, forests, shrub lands, grasslands and abandoned land [26]. RP, Pinus tabulaeformis Carr., Platycladus orientalis (L.) Franco. are the major 
arbor in forests. There are almost no shrubs under the RP forests, and the main herb species included Setaria viridis (L.) Beauv., Salsola collina Pall. and Artemisia hedinii Ostenf. et Pauls.

\subsection{Sample Plots}

Sample plots were selected in July 2018 along a RP recovering chronosequence. Five representative stand ages were selected, including 9, 14, 20, 32 and 41 years. Forest age was determined as follow: 5-8 trees were selected in each plot, and the tree core was drilled with a growth cone. The ages of the trees were determined by a tree ring analyzer, and the average tree age in the same plot was used as the forest age. Three $20 \mathrm{~m} \times 20 \mathrm{~m}$ plots, $50 \mathrm{~m}$ apart from each other, were selected in the middle of slopes for arbor investigation. Within each $20 \mathrm{~m} \times 20 \mathrm{~m}$ plot, three $1 \mathrm{~m} \times 1 \mathrm{~m}$ subplots were established in lower left, middle and upper right for herb survey. Arbor plots and herb subplots were fenced with wire to prevent human or wildlife interference. General characteristics of the sample plots were given in Table 1.

Table 1. Geographical characteristic of the sample sites.

\begin{tabular}{ccccccc}
\hline $\begin{array}{c}\text { Plot } \\
\text { Number }\end{array}$ & $\begin{array}{c}\text { Age } \\
(\text { Year) }\end{array}$ & $\begin{array}{c}\text { Altitude } \\
(\mathbf{m})\end{array}$ & $\begin{array}{c}\text { Slope } \\
\left.\mathbf{(}^{\circ}\right)\end{array}$ & $\begin{array}{c}\text { Aspect } \\
\left.\mathbf{(}^{\circ}\right)\end{array}$ & $\begin{array}{c}\text { Longitude } \\
\left.\mathbf{(}^{\circ}\right)\end{array}$ & $\begin{array}{c}\text { Latitude } \\
\left.\mathbf{(}^{\circ}\right)\end{array}$ \\
\hline 1 & 9 & 1299.4 & 21 & 36 & 109.2605 & 36.7339 \\
2 & 9 & 1298.6 & 22 & 60 & 109.2606 & 36.7341 \\
3 & 9 & 1286.1 & 32 & 54 & 109.2604 & 36.7335 \\
4 & 14 & 1283.3 & 21 & 47 & 109.2604 & 36.7331 \\
5 & 14 & 1259.1 & 19 & 70 & 109.2539 & 36.7353 \\
6 & 14 & 1274.7 & 20 & 73 & 109.2537 & 36.7355 \\
7 & 20 & 1273.2 & 19 & 65 & 109.2536 & 36.7354 \\
8 & 20 & 1309.5 & 22 & 83 & 109.2552 & 36.7320 \\
9 & 20 & 1267.0 & 19 & 81 & 109.2562 & 36.7338 \\
10 & 32 & 1263.1 & 13 & 62 & 109.2564 & 36.7641 \\
11 & 32 & 1268.5 & 15 & 51 & 109.2562 & 36.7341 \\
12 & 32 & 1267.8 & 16 & 15 & 109.2660 & 36.7346 \\
13 & 41 & 1073.7 & 19 & 87 & 109.2505 & 36.7452 \\
14 & 41 & 1072.4 & 18 & 157 & 109.2507 & 36.7450 \\
15 & 41 & 1121.8 & 21 & 140 & 109.2509 & 36.7450 \\
\hline
\end{tabular}

\subsection{Plant Investigation}

Vegetation investigation was conducted in August and September of 2018 when it was a period of vigorous for plant. Investigation of arbor and herb characteristics were conducted in corresponding (sub) plots. In the arbor plots, tree canopy (TC), diameter at breast height (DBH), tree height (TH), and crown base height $(\mathrm{CBH})$ indicating competition of target tree with neighborhoods were recorded. The canopy was estimated by sample point method, that is, randomly set 50 sample points in each plot to observe whether the crown covers the sample, the number of covered spots were counted and the canopy was calculated by the ratio of covered sample points to the total number of sample points (50 in our study). TH and $\mathrm{CBH}$ were measured using a height-adjustable gauge. The herb characteristics included species name, number of each species $(\mathrm{HN})$, coverage (HC), height $(\mathrm{HH})$ and ground diameter (HGD). The coverage was the percentage of herb vertical projection to the area of subplots. Vernier caliper was used for measuring of ground diameter and measuring tape for height. Herb diversity indexes using in our research are richness index (R), the Shannon-Wiener index (SW), and Pielou's index (J).

\subsection{Soil Sampling and Soil Analysis}

Ninety soil samples ( 15 sites $\times 3$ pits $\times 2$ soil depths) were collected in two diagonal lines using a standard soil auger ( $5 \mathrm{~cm}$ inner diameter) after removing the litter layer. Meanwhile, we collected soil samples using circle rings for water content measuring. Soil collected from the same plot was homogenized, and three $100 \mathrm{~g}$ subsamples were taken as 
representative. The subsamples were sieved through a $2 \mathrm{~mm}$ screen to remove discernible roots, stones and macro-fauna. We used sterile paper to wipe the remaining soil in auger and sieve to avoid contamination and keep samples fresh. The subsamples collected by soil auger were divided into two parts, one was stored at room temperature and air-dried before physicochemical analysis and one was stored at $4{ }^{\circ} \mathrm{C}$ until SMB analysis.

Soil bulk density (BD) was calculated as the ratio of oven dried soil mass and the volume of fresh soil obtained from cutting ring $\left(100 \mathrm{~cm}^{2}\right)$. Soil $\mathrm{pH}$ was determined in a 1:2.5 $(w / w)$ of dry soil to distilled water suspension using a glass electrode (Delta $320 \mathrm{pH}$ meter, Mettlere-Toledo Instruments Co., Ltd., Shanghai, China). Soil organic carbon (SOC) was determined by potassium dichromate oxidation - spectrophotometry method. Total nitrogen (TN) was determined by Kjeldahl method, nitrate content (NN) and ammonium nitrogen (AN) were determined using an automated continuous-flow auto analyzer after mixing with $1 \mathrm{~mol} / \mathrm{L} \mathrm{HCl}$ at a 1:1.5 (w/v) ratio. Total phosphorus (TP) content was measured by perchloric acid-sulfuric acid method, and available phosphorus (AP) content was measured by lixiviating-molybdenum blue colorimetry after diluting in $0.5 \mathrm{~mol} / \mathrm{L} \mathrm{NaHCO}_{3}$ for $30 \mathrm{~min}$. Determination of total potassium (TK) was via hydrofluoric acid-perchloric acid method, and available potassium (AK) via flame spectrophotometry method.

Microbial biomass C (MBC), microbial biomass $\mathrm{N}(\mathrm{MBN})$ and microbial biomass $\mathrm{P}$ (MBP) content were measured using the chloroform fumigation- $\mathrm{K}_{2} \mathrm{SO}_{4}$ extraction method. The content of $\mathrm{K}_{2} \mathrm{SO}_{4}$-extracted $\mathrm{C}$ was determined using a total organic carbon analyzer Phoenix 8000 (Teledyne Tekmar, Mason, OH, USA). Using a $\mathrm{K}_{\mathrm{EC}}$ factor of 0.45 as the correction coefficient to estimating MBC by converting the extractable $C$, which is the difference in the TOC between the fumigated and non-fumigated samples. MBN and MBP content was determined in the same method as $\mathrm{MBC}$, with $\mathrm{K}_{\mathrm{EN}}=0.54, \mathrm{~K}_{\mathrm{EP}}=0.4$.

\subsection{Data Analysis}

Before conducting analysis, we normalize all plant, soil and topographical variables and obtained Z-score values for further analysis using "decostand" function in vegan package in R version 3.4.1 (https: / / www.r-project.org/) to eliminate the statistical errors caused by the different dimensions of the variables and improve the accuracy and credibility of the results.

For convenience of further analysis and interpretations, we grouped all explanatory variables into 4 groups (1) P (plant; Age, TH, DBH, TC, CBH, HN, HH, HGD, HC, R, SW, J); (2) S1 (soil at 0-10 cm; AN1, NN1, TN1, SOC1, AP1, BD1, PH1, TP1, AK1, SWC1); (3) S2 (soil at 10-30 cm; AN2, NN2, TN2, SOC2, AP2, BD2, PH2, TP2, AK2, SWC2); (4) T (topography; Elevation, Slope and Aspect).

In order to rule out the problem of collinearity between explanatory variables and the corresponding instability of regression coefficients, we deleted the explanatory factors that have a strong correlation with other variables using "find correlation" function and excluded the multiple collinearity problem between variables using "find Linear Combos" function in Caret package in R. By doing this, we got TC, HGD, R, SW, J for group P; AN1, TN1, SOC1, AP1, BD1, AK1, SWC1 for group S1; AN2, NN2, TN2, SOC2, AP2, BD2, AK2, SWC2 for group S2. No correlation was observed among topographical factors. The selected variables were used for further analysis.

The main driving factors of SMB in different depths among each group were identified using the forward selection analysis by the "forward.sel" function in packfors package in R. The "forward.sel" function takes the $\mathrm{R}^{2}$ of the full model containing all explanatory variables as the termination principle, selects the variable with the highest proportion of the total variance, and constructs a simple model containing only the most significant variables. The significance of the reduced model was assessed using "anova.cca" function in vegan package in $R$. The variance inflation factor (VIF) of each explanatory variable in the reduced model was assessed by "vif.cca" function in vegan package in R. If the value is less than 10 , there is no obvious collinearity between the explanatory variables. 
Principal components analysis (PCA) was conducted based on variables selected by the forward selection analysis to create a new index that stand for each group. The PCA results showed that the PC1 explained $54.41-97.71 \%$ of the total variance for each group (Table 2). Due to the complexity of ecological data, we should be satisfied with such results, and it is credible to use PC 1 for general linear model (GLM) analysis to identify the interactive effects of plant, soil and topographical factors on SMB. The GLM analysis was conducted using "glm" function in R with Gaussian-family.

Table 2. Results of principal components analysis (PCA) of plant and soil.

\begin{tabular}{|c|c|c|c|c|}
\hline Layer & & Group & Variables & PC1 \\
\hline \multirow{3}{*}{$0-10$} & MBN1 & $\begin{array}{c}\text { P } \\
\text { Cummulative (\%) } \\
\text { S1 } \\
\text { Cummulative (\%) }\end{array}$ & $\begin{array}{c}\mathrm{TC} \\
\mathrm{R} \\
53.32 \\
\mathrm{AP1} \\
\mathrm{BD} 1 \\
51.82\end{array}$ & $\begin{array}{c}-70.7 \\
-70.7 \\
-70.7 \\
70.7\end{array}$ \\
\hline & MBC1 & $\begin{array}{c}\text { S1 } \\
\text { Cummulative (\%) } \\
\text { P } \\
\text { Cummulative (\%) }\end{array}$ & $\begin{array}{l}\text { AN1 } \\
\text { TN1 } \\
68.4 \\
\text { TC } \\
\text { R } \\
53.32\end{array}$ & $\begin{array}{l}70.7 \\
70.7 \\
-70.7 \\
-70.7\end{array}$ \\
\hline & MBP1 & $\begin{array}{c}\text { S1 } \\
\text { Cummulative (\%) }\end{array}$ & $\begin{array}{l}\text { SOC1 } \\
\text { AP1 } \\
58.10\end{array}$ & $\begin{array}{c}-70.7 \\
70.7\end{array}$ \\
\hline \multirow{2}{*}{$10-30$} & MBN2 & $\begin{array}{l}\text { Cummulative (\%) } \\
\text { P }\end{array}$ & $\begin{array}{l}\text { AN2 } \\
\text { NN2 } \\
\text { TN2 } \\
65.27 \\
\text { TC } \\
\text { R } \\
53.32\end{array}$ & $\begin{array}{l}-38.8 \\
-60.4 \\
-69.6 \\
-70.7 \\
-70.7\end{array}$ \\
\hline & MBP2 & Cummulative (\%) & $\begin{array}{l}\text { SOC2 } \\
\text { AP2 } \\
\text { AK2 } \\
71.17\end{array}$ & $\begin{array}{c}52.8 \\
62.9 \\
-57.1\end{array}$ \\
\hline
\end{tabular}

Values mean the correlation coefficient between the variables and scores for rows in the main matrix (PC1). MBN1, MBC1, MBP1, microbial biomass N, C, P at 0-10 cm; MBN 2, MBP2, microbial biomass N, C, P at 10-30 cm; P, plant characteristics; $\mathrm{S} 1$, soil characteristics at $0-10 \mathrm{~cm}$; S2, soil characteristics at 10-30 cm; TC, tree canopy; R, herb richness; AP1, available phosphorus at 0-10 cm; BD1, bulk density at 0-10 cm; AN1, available nitrogen at 0-10 cm; $\mathrm{TN} 1$, total nitrogen at $0-10 \mathrm{~cm}$; SOC1, soil organic carbon at $0-10 \mathrm{~cm}$; AN2, available nitrogen at 10-30 cm; NN2, nitrate content at 10-30 cm; TN2, total nitrogen at 10-30 cm; SOC2, soil organic carbon at 10-30 cm; AP2, available phosphorus at 10-30 cm; AK2, available potassium at 10-30 cm.

\section{Results}

\subsection{Forward Selection: The Main Drivers for SMB in Different Soil Depth}

The reduced models for SMB containing the most significant variables at different soil depth were constructed by forward selection. These models were acceptable because: (1) these models contain the least amount of explanatory variables, but the $R^{2}$ is equal to $\mathrm{R}^{2}$ of the model containing all explanatory variables, indicating that the quality of the model can be improved by reducing the explanatory variables; (2) the VIF value of each explanatory variable in the reduced model is less than 10, indicating that there is no significant collinearity between the explanatory variables.

Soil and vegetation factors that have the greatest impact on SMB were different at different soil depths (Table 3). For example, MBN at $0-10 \mathrm{~cm}$ was mainly affected by AP and $\mathrm{BD}$, while mainly affected by $\mathrm{AN}, \mathrm{TN}$ and $\mathrm{NN}$ at $10-30 \mathrm{~cm}$. The main driving soil factors for MBP were AP and SOC both at 0-10 and at 10-30 cm. Among all of the plant 
properties, TC and R were the main drivers for MBN, MBC and MBP in all layers, except for a significant effect of HGD on MBP at 10-30 cm. The most significant topographical factor was altitude in both layers (Table 3).

Table 3. Main drivers of soil microbial biomass (SMB) for different groups in different layers.

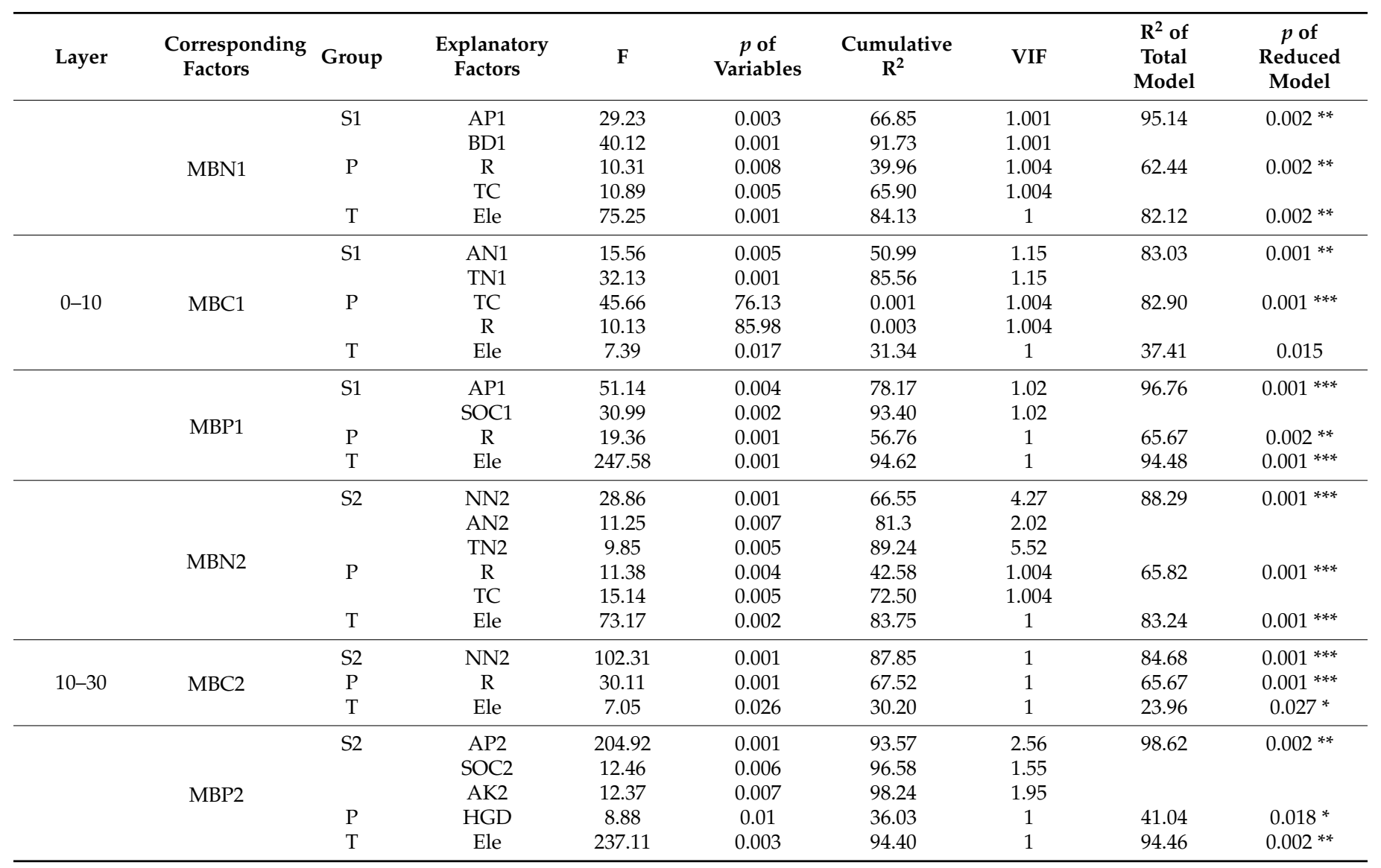

MBN1, MBC1, MBP1, microbial biomass N, C, P at 0-10 cm; MBN2, MBP2, microbial biomass N, C, P at 10-30 cm; P, plant characteristics; $\mathrm{S} 1$, soil characteristics at $0-10 \mathrm{~cm} ; \mathrm{S} 2$, soil characteristics at $10-30 \mathrm{~cm} ; \mathrm{T}$, topographical variables. ${ }^{*}$ represents the significance of $p<0.05$; ** represents the significance of $p<0.01 ;{ }^{* * *}$ represents the significance of $p<0.001$.

\subsection{Effect of Plant, Soil, Topography and Their Interaction on $S M B$}

GLM analysis demonstrated that SMB at 0-10 $\mathrm{cm}$ was affected by individual factors while interaction among these factors mainly acted at 10-30 $\mathrm{cm}$ (Table 4). The GLM results also showed that MBN, MBC and MBP were affected by different factors in different depths. Soil factors were the most significant factors affecting MBN at $0-10 \mathrm{~cm}$, topographical factors affecting MBP, while plant and topographical factors both played important roles in affecting MBC. MBC at 10-30 cm was affected by soil-plant-topography interactions, MBP was affected by soil-topography interaction while no significant interactive effects were observed for MBN at 10-30 cm (Table 4). 
Table 4. General linear model (GLM) results for SMB in different depths as affected by soil, plant, topography and their interaction.

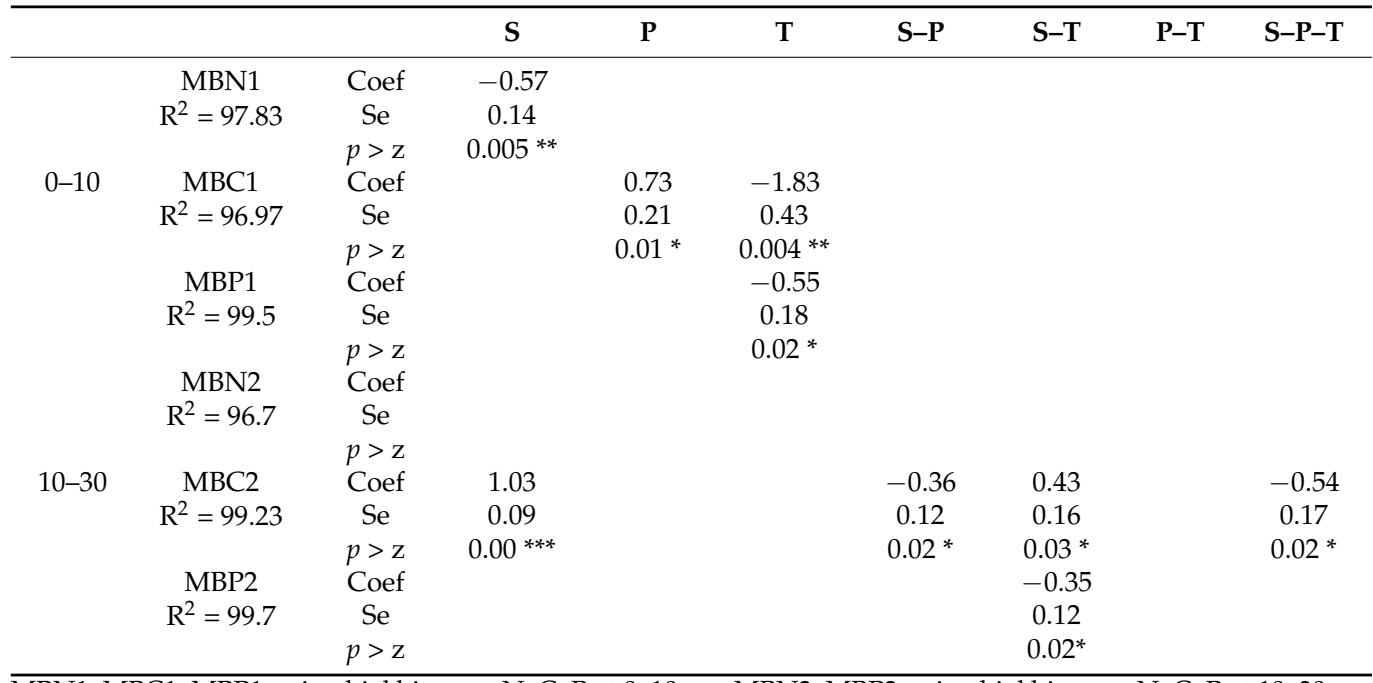

MBN1, MBC1, MBP1, microbial biomass N, C, P at 0-10 cm; MBN2, MBP2, microbial biomass N, C, P at 10-30 cm $\mathrm{P}$, plant characteristics; $\mathrm{S}$, soil characteristics at $0-10 \mathrm{~cm} ; \mathrm{T}$, topographical variables; $\mathrm{S}-\mathrm{P}$, interactions between soil and plant; $\mathrm{S}-\mathrm{T}$, interactions between soil and topography; $\mathrm{P}-\mathrm{T}$, interactions between plant and topography; S-P-T, interactions among plant, soil and topography. ${ }^{*}$ Represents the significance of $p<0.05$; ${ }^{* *}$ Represents the significance of $p<0.01 ; * * *$ Represents the significance of $p<0.001$.

\section{Discussion}

Our aims were to identify the main drivers of SMB and to understand the collective effect of plant, soil, and topographical properties on SMB across different soil depths at a regional scale. We used forward selection to determine the main driving factors and GLM to evaluate the interactive effects among plant, soil and topography on SMB at different depths.

\subsection{Effect of Plant Properties on $S M B$}

Plant factors significantly affected $\mathrm{MBC}$ at $0-10 \mathrm{~cm}$ (Table 4 ). The plant inputs a large amount of litter to the surface soil, which provide abundant carbon source for MBC [27]. Forward selection showed that canopy density and understory richness were the major vegetation factors in modulating SMB at $0-10 \mathrm{~cm}$ in PR planation forests (Table 3). It is commonly believed that high canopy density forests produce more litter which provides a large amount of carbon source material and is beneficial to the growth and reproduction of soil microorganisms. However, there was significantly negative correlation between MBC and TC at $0-10 \mathrm{~cm}$ in our research (Figure S1). Therefore, we supposed that it is the decomposition rate of litter rather than amount of litter affecting MBC. The rate of decomposition was reported to be positively related with air temperature and moisture [28]. Increased temperature and humidity enhanced microbial activity and therefor SMB. Stands with low canopy density means high canopy openness leading to relative high air temperature and moisture in soil surface and therefore high decomposition rate and high SMB content.

Forward selection results also showed that $\mathrm{R}$ was another important plant characteristic in determining SMB (Table 3), indicating that changes of SMB in RP forests were mainly due to the presence of a particular plant species or a particular plant functional group [29]. We supposed that the particular plant functional groups may be related to the specific root structure of some plants. In the Loess hilly region, the plants including RP are mostly restricted by P [30]. Under P-limited conditions, the absorption of $\mathrm{P}$ by plant depends mainly on the change in root system, such as changing root morphological characteristics, inducing acid phosphatase secretion or producing specific root exudates [31]. 


\subsection{Effect of Soil Properties on $S M B$}

Soil factors significantly affected MBN at $0-10 \mathrm{~cm}$ layer and $M B C$ at $10-30 \mathrm{~cm}$ (Table 4). Effect of nitrogen on SMB has been reported by many other authors [32]. The forward selection result showed that BD had good explanation for MBN (Table 3). This finding is consistent with that of $\mathrm{Li}$ et al., who found that an increase in BD was quadratically related to soil enzyme activity, indicating an increase in microbial activity and SMB [33].

Our research also indicated that SMB at different depths in RP forests in the Loess hilly region is limited by AP content (Table 3). P in terrestrial ecosystems is almost entirely derived from the weathering of mineral rocks [34]. Plants absorb P from the soil through the roots, and then the $\mathrm{P}$ is returned to the soil by litter decomposition. In an undisturbed ecosystem, $\mathrm{P}$ forms a complete cycle between the organism and the soil, with little loss of P [35]. However, as the forest degraded in the Loess hilly region, soil erosion and phosphorus loss were high and associated with more rain, which was converted to surface runoff. Previous researches indicated that even if $70-89 \%$ of the P lost from soils is re-deposited within catchments, the potential threats of $P$ loss from soils are not reduced [36-39]. Studies have shown that with the implementation of afforestation projects, soil erosion in this area has been effectively controlled [40], and soil and vegetation P elements have increased [30]. However, there is no research on the P cycle in the RP forests. Our study shows that the SMB as a soilvegetation interaction bond is still limited by $\mathrm{P}$, indicating that the $\mathrm{P}$ cycle in the RP forest is still unbalanced. Our result confirmed that the ecological function of RP in the Loess hilly region is gradually declining and it is urgent to take steps to prevent further declining of RP.

\subsection{Effect of Topography on $S M B$}

Forward selection results showed that altitude was the most important topographical driving factor for SMB in RP forests rather than slope and aspect (Table 3). It is commonly believed that response of SMB to altitude depends on plant and soil characteristics [41]. However, the GLM results showed that topography significantly affected SMB at $0-10 \mathrm{~cm}$, while the interaction among topography and plant-soil was insignificant (Table 4), indicating that SMB at $0-10 \mathrm{~cm}$ was directly affected by topography. Previous studies have also demonstrated a direct association between topography (especially altitude) and soil microorganisms [41]. Two possible reasons could explain this phenomenon. (1) Temperature decreases with the elevation, and the high temperature can improve the activity of microbes [42]. Therefore, elevation affected SMB at $0-10 \mathrm{~cm}$ by changing microbial activity rather than by changing input of plant materials and soil nutrient availability. (2) The MBC/MBN ratio reflects the relative proportion of fungi and bacteria in soil, and it can be used as an indication of the relative proportion of fungi to bacteria [43]. A low $\mathrm{MBC} / \mathrm{MBN}$ ratio indicates that the microbial biomass contains a higher proportion of bacteria whereas a high value suggests that fungi predominate in the microbial population [44]. The MBC/MBN ratios obtained in this study were relatively low, $1.0-2.9$ at $0-10 \mathrm{~cm}$ and $1.0-3.1$ at $10-30 \mathrm{~cm}$ (Table S2, Supplementary Materials), indicating the predominance of bacterial in these soils. Soil bacterial diversity was affected by altitude gradients while fungal diversity did not affect by altitude gradients [41]. Therefore, we suggested that changes in SMB with altitude may be related to soil microbial species.

\subsection{Interactive Effect of Abiotic and Biotic Factors on $S M B$}

We observed that significantly interactive effect only occurred at 10-30 cm (Table 4). This result indicated that the plant, soil and topographical factors do interact, affecting the $\mathrm{SMB}$, but that the interactive effects depend on soil depth. We suggest that the possible reason may be the rhizosphere effect. The rhizosphere refers to the millimeters of soil that directly surround a root [45]. Studies have shown that the roots of herbaceous plants in the Loess hilly region are concentrated at $0-40 \mathrm{~cm}$ and absorptive root are mainly distributed at 20-40 cm [46]. Due to the action of root exudates, the rhizosphere microbial activity and species are significantly different from the bulk soil [47]. Tian et al. [48] showed that larger bacteria and actinomycete counts were found at $10-20 \mathrm{~cm}$ soil depths than at other 
depths in reed rhizospheric soils. Thus, we concluded that interactive effect of soil and plant on SMB at 10-30 cm was the result of higher rhizosphere effects on this layer, and the rhizosphere effects were connected with topographical factors especially altitude.

\section{Conclusions}

The influencing factors on SMB in different depths for RP plantations in the Loess hilly region were examined from above and below abiotic and biotic aspects.

TC affected SMB by changing decomposition rate rather than amount of litter. R affected SMB via the specific root structure of plants in the special natural condition in the Loess hilly region. $\mathrm{BD}$ and $\mathrm{AP}$ were the most significant soil factors, indicating low activities and P-limited loess soil for microorganism. Effect of elevation on SMB may be connected with soil microbial species.

We found that the individual effect of abiotic and biotic factors significantly affected SMB at $0-10 \mathrm{~cm}$, while interactive effects of these factors mainly play roles at $10-30 \mathrm{~cm}$, which we supposed to be the result of rhizosphere effects.

Additional studies are required to further investigate the dynamics and mechanisms of SMB on global scale. We also recommend quantifying the contribution of SMB in maintaining soil fertility and ecosystem productivity.

Supplementary Materials: The following are available online at https://www.mdpi.com/1999-4 907/12/4/501/s1, Table S1: Plant factors in sample plots, Figure S1: Semi-matrices of Pearson correlation coefficients between SMB and biotic and abiotic factors at 0-10 cm (a) and 10-30 cm (b), Table S2: Soil physiochemical factors and SMB in sample plots at different depths.

Author Contributions: Conceptualization, W.X. and Y.C.; methodology, W.X.; software, W.X.; validation, W.X. and Y.C.; formal analysis, W.X. and Y.C.; investigation, W.X., C.D. and Y.Q.; resources, W.X., C.D. and Y.Q.; data curation, W.X.; writing—original draft preparation, W.X.; writing—review and editing, Y.C.; visualization, Y.C.; supervision, Y.C.; project administration, Y.C.; funding acquisition, Y.C. All authors have read and agreed to the published version of the manuscript.

Funding: This research was funded by the National Natural Science Foundation of China, grant numbers 41771556 and 41977418.

Institutional Review Board Statement: Not applicable.

Informed Consent Statement: Not applicable.

Data Availability Statement: The data presented in this study are available on request from the corresponding author.

Acknowledgments: We wish to acknowledge Wenhui Zhang from Northwest A\&F University for his help in revising our manuscript. We also thank the editor and anonymous reviewers for their contribution to the peer reviews of our study.

Conflicts of Interest: The authors declare no conflict of interest.

\section{References}

1. Singh, J.S. Microbes: The chief ecological engineers in reinstating equilibrium in degraded ecosystems. Agric. Ecosyst. Environ. 2015, 203, 80-82. [CrossRef]

2. Roy, K.; Ghosh, D.; Debruyn, J.M.; Dasgupta, T.; Wommack, K.E.; Liang, X.; Wagner, R.E.; Radosevich, M. Temporal Dynamics of Soil Virus and Bacterial Populations in Agricultural and Early Plant Successional Soils. Front. Microbiol. 2020, 11, 1494. [CrossRef]

3. Spohn, M.; Widdig, M. Turnover of carbon and phosphorus in the microbial biomass depending on phosphorus availabil-ity. Soil Biol. Biochem. 2017, 113, 53-59. [CrossRef]

4. Liang, X.; Zhuang, J.; Löffler, F.E.; Zhang, Y.; DeBruyn, J.M.; Wilhelm, S.W.; Schaeffer, S.M.; Radosevich, M. Viral and bacterial commu-nity responses to stimulated Fe (III)-bioreduction during simulated subsurface bioremediation. Environ. Microbiol. 2019, 21, 2043-2055. [CrossRef]

5. Lladó, S.; López-Mondéjar, R.; Baldrian, P. Drivers of microbial community structure in forest soils. Appl. Microbiol. Biotechnol. 2018, 102, 4331-4338. [CrossRef]

6. Kaschuk, G.; Alberton, O.; Hungria, M. Three decades of soil microbial biomass studies in Brazilian ecosystems: Lessons learned about soil quality and indications for improving sustainability. Soil Biol. Biochem. 2010, 42, 1-13. [CrossRef] 
7. Singh, J.S.; Gupta, V.K. Soil microbial biomass: A key soil driver in management of ecosystem functioning. Sci. Total Environ. 2018, 634, 497-500. [CrossRef]

8. Vimal, S.R.; Singh, J.S.; Arora, N.K.; Singh, S. Soil-Plant-Microbe Interactions in Stressed Agriculture Management: A Review. Pedosphere 2017, 27, 177-192. [CrossRef]

9. Lange, M.; Eisenhauer, N.; Sierra, C.A.; Bessler, H.; Engels, C.; Griffiths, R.I.; Mellado-Vázquez, P.G.; Malik, A.A.; Roy, J.; Scheu, S.; et al. Plant diversity increases soil microbial activity and soil carbon storage. Nat. Commun. 2015, 6, 6707. [CrossRef] [PubMed]

10. Sanaei, A.; Chahouki, M.A.Z.; Ali, A.; Jafari, M.; Azarnivand, H. Abiotic and biotic drivers of aboveground biomass in semi-steppe rangelands. Sci. Total Environ. 2018, 615, 895-905. [CrossRef] [PubMed]

11. Li, H.; Yang, S.; Xu, Z.; Yan, Q.; Li, X.; van Nostrand, J.D.; He, Z.; Yao, F.; Han, X.; Zhou, J.; et al. Responses of soil microbial functional genes to global changes are indirectly influenced by aboveground plant biomass variation. Soil Biol. Biochem. 2017, 104, 18-29. [CrossRef]

12. Chen, Y.-L.; Ding, J.-Z.; Peng, Y.-F.; Li, F.; Yang, G.-B.; Liu, L.; Qin, S.-Q.; Fang, K.; Yang, Y.-H. Patterns and drivers of soil microbial communities in Tibetan alpine and global terrestrial ecosystems. J. Biogeogr. 2016, 43, 2027-2039. [CrossRef]

13. Liu, M.; Liu, J.; Jiang, C.; Wu, M.; Song, R.; Gui, R.; Jia, J.; Li, Z. Improved nutrient status affects soil microbial biomass, respiration, and functional diversity in a Lei bamboo plantation under intensive management. J. Soils Sediments 2016, 17, 917-926. [CrossRef]

14. Liao, H.; Chapman, S.J.; Li, Y.; Yao, H. Dynamics of microbial biomass and community composition after short-term water status change in Chinese paddy soils. Environ. Sci. Pollut. Res. 2017, 25, 2932-2941. [CrossRef]

15. Hsiao, C.-J.; Sassenrath, G.F.; Zeglin, L.H.; Hettiarachchi, G.M.; Rice, C.W. Vertical changes of soil microbial properties in claypan soils. Soil Biol. Biochem. 2018, 121, 154-164. [CrossRef]

16. Gilliam, F.S.; Hédl, R.; Chudomelová, M.; McCulley, R.L.; Nelson, J.A. Variation in vegetation and microbial linkages with slope aspect in a montane temperate hardwood forest. Ecosphere 2014, 5, art66. [CrossRef]

17. Taş, N.; Prestat, E.; Wang, S.; Wu, Y.; Ulrich, C.; Kneafsey, T.; Tringe, S.G.; Torn, M.S.; Hubbard, S.S.; Jansson, J.K. Landscape topography structures the soil microbiome in arctic polygonal tundra. Nat. Commun. 2018, 9, 1-13. [CrossRef]

18. Hook, P.B.; Burke, I.C. Biogeochemistry in a shortgrass landscape: Control by topography, soil texture, and microclimate. Ecology 2000, 81, 2686-2703. [CrossRef]

19. Fu, B.; Liu, Y.; Lü, Y.; He, C.; Zeng, Y.; Wu, B. Assessing the soil erosion control service of ecosystems change in the Loess Plateau of China. Ecol. Complex. 2011, 8, 284-293. [CrossRef]

20. Jia, X.; Shao, M.; Zhu, Y.; Luo, Y. Soil moisture decline due to afforestation across the Loess Plateau, China. J. Hydrol. 2017, 546, 113-122. [CrossRef]

21. Yang, K.; Lu, C. Evaluation of land-use change effects on runoff and soil erosion of a hilly basin-the Yanhe River in the Chinese Loess Plateau. Land Degrad. Dev. 2018, 29, 1211-1221. [CrossRef]

22. Liang, H.; Xue, Y.; Li, Z.; Wang, S.; Wu, X.; Gao, G.; Liu, G.; Fu, B. Soil moisture decline following the plantation of Robinia pseudoacacia forests: Evidence from the Loess Plat-eau. For. Ecol. Manag. 2018, 412, 62-69. [CrossRef]

23. Qin, J.; Xi, W.; Rahmlow, A.; Kong, H.; Zhang, Z.; Shangguan, Z. Effects of forest plantation types on leaf traits of Ulmus pumila and Robinia pseudoacacia on the Loess Plateau, China. Ecol. Eng. 2016, 97, 416-425. [CrossRef]

24. Kou, M.; Garcia-Fayos, P.; Hu, S.; Jiao, J. The effect of Robinia pseudoacacia afforestation on soil and vegetation properties in the Loess Plateau (China): A chronosequence approach. For. Ecol. Manag. 2016, 375, 146-158. [CrossRef]

25. Wei, J.S.; Li, Z.S.; Feng, X.Y.; Zhang, Y.; Chen, W.L.; Wu, X.; Jiao, L.; Wang, X.C. Ecological and physiological mechanisms of growth decline of Robinia pseudoacacia plantations in the Loess Plateau of China: A review. Ying yong sheng tai xue bao J. Appl. Ecol. 2018, 29, 2433-2444.

26. Jiao, J.; Zhang, Z.; Bai, W.; Jia, Y.; Wang, N. Assessing the Ecological Success of Restoration by Afforestation on the Chinese Loess Plateau. Restor. Ecol. 2010, 20, 240-249. [CrossRef]

27. Santonja, M.; Rancon, A.; Fromin, N.; Baldy, V.; Hättenschwiler, S.; Fernandez, C.; Montès, N.; Mirleau, P. Plant litter diversity increases microbial abundance, fungal diversity, and carbon and nitrogen cycling in a Mediterranean shrubland. Soil Biol. Biochem. 2017, 111, 124-134. [CrossRef]

28. Sierra, C.A.; Malghani, S.; Loescher, H.W. Interactions among temperature, moisture, and oxygen concentrations in controlling decomposition rates in a boreal forest soil. Biogeosciences 2017, 14, 703-710. [CrossRef]

29. García-Palacios, P.; Vandegehuchte, M.L.; Shaw, E.A.; Dam, M.; Post, K.H.; Ramirez, K.S.; Sylvain, Z.A.; De Tomasel, C.M.; Wall, D.H. Are there links between responses of soil microbes and ecosystem functioning to elevated CO2, N deposition and warming? A global perspective. Glob. Chang. Biol. 2014, 21, 1590-1600. [CrossRef]

30. Xing, K.; Zhao, M.; Chen, C.; Wang, Y.; Xue, F.; Zhang, Y.; Dong, X.; Jiang, Y.; Chen, H.Y.H.; Kang, M. Leaf phosphorus content ofQuercus wutaishanicaincreases with total soil potassium in the Loess Plateau. PLoS ONE 2018, 13, e0201350. [CrossRef]

31. Hou, X.; Tigabu, M.; Zhang, Y.; Ma, X.; Cai, L.; Wu, P.; Liu, A.; Wang, C.; Qiu, H. Root plasticity, whole plant biomass, and nutrient accumulation of Neyraudia reynaudiana in response to het-erogeneous phosphorus supply. J. Soils Sediments 2017, 17, 172-180. [CrossRef]

32. Li, L.J.; Zhu-Barker, X.; Ye, R.; Doane, T.A.; Horwath, W.R. Soil microbial biomass size and soil carbon influence the priming effect from carbon inputs depending on nitro-gen availability. Soil Biol. Biochem. 2018, 119, 41-49. [CrossRef]

33. Li, C.H.; Ma, B.L.; Zhang, T.Q. Soil bulk density effects on soil microbial populations and enzyme activities during the growth of maize (Zea mays L.) planted in large pots under field exposure. Can. J. Soil Sci. 2002, 82, 147-154. [CrossRef] 
34. Newman, E.I. Phosphorus Inputs to Terrestrial Ecosystems. J. Ecol. 1995, 83, 713. [CrossRef]

35. Cade-Menun, B.J.; Elkin, K.R.; Liu, C.W.; Bryant, R.B.; Kleinman, P.J.A.; Moore, P.A., Jr. Characterizing the phosphorus forms extracted from soil by the Mehlich III soil test. Geochem. Trans. 2018, 19, 1-17. [CrossRef]

36. Wei, W.; Chen, L.; Fu, B.; Huang, Z.; Wu, D.; Gui, L. The effect of land uses and rainfall regimes on runoff and soil erosion in the semi-arid loess hilly area, China. J. Hydrol. 2007, 335, 247-258. [CrossRef]

37. Alewell, C.; Ringeval, B.; Ballabio, C.; Robinson, D.A.; Panagos, P.; Borrelli, P. Global phosphorus shortage will be aggravated by soil erosion. Nat. Commun. 2020, 11, 1-12. [CrossRef]

38. Yin, J.; Gentine, P.; Zhou, S.; Sullivan, S.C.; Wang, R.; Zhang, Y.; Guo, S. Large increase in global storm runoff extremes driven by climate and anthropogenic changes. Nat. Commun. 2018, 9, 1-10. [CrossRef]

39. Wei, F.; Yunfen, Y.; Yongjun, Z.; Baofeng, D.; Changchen, M. The Implementation Effects of a Nationwide Sloping Farmland Soil Erosion Control Project in China. J. Resour. Ecol. 2017, 8, 341-351. [CrossRef]

40. Ren, C.; Zhang, W.; Zhong, Z.; Han, X.; Yang, G.; Feng, Y.; Ren, G. Differential responses of soil microbial biomass, diversity, and compositions to altitudinal gradients depend on plant and soil characteristics. Sci. Total Environ. 2018, 610-611, 750-758. [CrossRef]

41. Li, W.; Yang, G.; Chen, H.; Tian, J.; Zhang, Y.; Peng, C. Soil available nitrogen, dissolved organic carbon and microbial biomass content along altitudinal gradient of the eastern slope of Gongga Mountain. Acta Ecol. Sin. 2013, 33, 266-271. [CrossRef]

42. Anderson, J.P.E.; Domsch, K.H. Quantities of plant nutrients in the microbial biomass of selected soils. Soil Sci. 2006, 171, S106-S111. [CrossRef]

43. Adeboye, M.K.A.; Bala, A.; Osunde, A.O.; Uzoma, A.O.; Odofin, A.J.; Lawal, B.A. Assessment of soil quality using soil organic carbon and total nitrogen and microbial properties in tropical agroecosystems. Agric. Sci. 2011, 2, 34-40. [CrossRef]

44. Nuccio, E.E.; Anderson-Furgeson, J.; Estera, K.Y.; Pett-Ridge, J.; De Valpine, P.; Brodie, E.L.; Firestone, M.K. Climate and edaphic controllers influence rhizosphere community assembly for a wild annual grass. Ecology 2016, 97, 1307-1318. [CrossRef]

45. Li, P. Root distribution characteristics of natural grassland on loess plateau. Res. Soil Water Conserv. 2003, 10, 144-145+149.

46. Das, S.; Chou, M.-L.; Jean, J.-S.; Yang, H.-J.; Kim, P.J. Arsenic-enrichment enhanced root exudates and altered rhizosphere microbial communities and activities in hyperaccumulator Pteris vittata. J. Hazard. Mater. 2017, 325, 279-287. [CrossRef]

47. Shi, W.; Li, M.; Wei, G.; Tian, R.; Li, C.; Wang, B.; Lin, R.; Shi, C.; Chi, X.; Zhou, B.; et al. The occurrence of potato common scab correlates with the community composition and function of the geo-caulosphere soil microbiome. Microbiome 2019, 7, 1-18. [CrossRef]

48. Tian, W.; Zhao, Y.; Sun, H.; Bai, J.; Wang, Y.; Wu, C. The effect of irrigation with oil-polluted water on microbial communities in estuarine reed rhizosphere soils. Ecol. Eng. 2014, 70, 275-281. [CrossRef] 